\title{
Cadmium stress in Dongying wild soybean seedlings: growth, Cd accumulation, and photosynthesis
}

\author{
L. LIU*, Y.K. SHANG*, L. LI*, Y.H. CHEN*, Z.Z. QIN*, L.J. ZHOU*, M. YUAN*, C.B. DING ${ }^{*}$, J. LIU*, Y. \\ HUANG $^{*}$, R.W. YANG ${ }^{*}$, Y.H. ZHOU, and J.Q. LIAO ${ }^{*+}$ \\ College of Life Science, Sichuan Agricultural University, Yaan 625014, China* \\ Triticeae Research Institute, Sichuan Agricultural University, Wengjiang 611130, China
}

\begin{abstract}
In order to understand better Cd resistance in soybean, Dongying wild soybean treated with different Cd concentrations were evaluated. The biomass, chlorophyll (Chl) content, leaf color, Chl a fluorescence parameters, photosynthesis parameters, and $\mathrm{Cd}$ contents were determined. Our results showed that when Cd concentration was $\leq 2 \mathrm{~kg} \mathrm{~m}{ }^{-3}$, no significant decrease in biomass, photosynthetic parameters, and maximal photochemical efficiency of PSII was observed. This indicated that Dongying wild soybean resisted Cd toxic effects under such conditions. In addition, atomic absorption experiment results demonstrated that when $\mathrm{Cd}$ concentration was $\leq 0.5 \mathrm{~kg} \mathrm{~m}^{-3}$, the accumulation of Cd in wild soybean was lower in roots than that in shoots, while the accumulation of $\mathrm{Cd}$ was higher in roots than that in shoots when $\mathrm{Cd}$ concentration was $\geq 1 \mathrm{~kg} \mathrm{~m}^{-3}$. Therefore, Dongying wild soybean showed a certain resistance to Cd and could serve as a valuable germplasm resource for improving the breeding of Cd-resistant soybean.
\end{abstract}

Additional key words: atomic absorption spectrophotometry; Glycine soja; growth analysis; pigment.

\section{Introduction}

Heavy metal $\mathrm{Cd}$ is widely spread in the nature and it is a non-nutritive element in plants. Cd content is generally around $0.01-0.7 \mathrm{mg} \mathrm{kg}^{-1}$ in soil (Kovalchuk et al. 2001, Ünyayar et al. 2006). The Cd content in cultivated lands has increased from the use of chemical substances and mine exploitation that go hand-in-hand with city development. In recent years, the metal pollution of farm land affected about $20 \%$ of the arable land in China, and the pollution by $\mathrm{Cd}$ was found to be higher than those of other heavy metals (Wei et al. 2010, Wang et al. 2015). Cd in soil has become a widespread phenomenon in China, threatening the health of people (Zhao et al. 2010). The second large-scale survey in China showed that the standard rate of $\mathrm{Cd}$ pollution was $7 \%$ among all sampling sites (Wang et al. 2015). Cd in rural soil was $1.121 \mathrm{mg} \mathrm{kg}^{-}$ , while that in urban soils it was $0.357 \mathrm{mg} \mathrm{kg}^{-1}$ in Sichuan (Wang et al. 2015).

Due to its high toxicity and solubility, $\mathrm{Cd}$ is a particularly dangerous pollutant (Duxbury et al. 1985, Jiang et al. 2001). The growth of plants is extremely inhibited by Cd stress. For example, the root development and cell division in Allium cepa, Tradescantia ohiensis, Vicia faba, Nicotiana tabacum, and Allium sativum have been reported to be inhibited by $\mathrm{Cd}$ (Steinkellner et al. 1998, Fojtová et al. 2000, Yi et al. 2003). Moreover, the physiological and biochemical processes of plants, such as photosynthetic reactions (Wu et al. 2007, Sun et al. 2008, Ci et al. 2010) and Chl biosynthesis (Myśliwa-Kurdziel et al. 2002), have been also shown as affected. When exposed to Cd, Lhcb1 and Lhcb2 were observed to be dissipated and LHCII aggregation complexes were found to be diminished in plants (Janik et al. 2010). In addition, both acceptor and donor sides of PSII were affected which led to the prevention of photoactivation (Sigfridsson et al. 2004). In addition, PSI was found to be damaged under $\mathrm{Cd}$ stress (Timperio et al. 2007). Taken together, photosynthesis is extremely inhibited by Cd stress.

The subgenus soja in Glycine includes only two species: the cultivated soybean [Glycine $\max$ (L.) Merr.] and wild soybean (Glycine soja Sieb. et Zucc.)

Received 6 July 2017, accepted 9 March 2018, published as online-first 27 June 2018.

${ }^{+}$Corresponding author; phone: +86-835-2886124, e-mail: liaojinqiu630@sicau.edu.cn

Abbreviations: $\mathrm{Car}$ - carotenoids; $\mathrm{Chl}$ - chlorophyll; $\mathrm{CF}$ - chlorophyll fluorescence; $C_{\mathrm{i}}-$ intercellular $\mathrm{CO}_{2}$ concentration; $\mathrm{DM}-\mathrm{dry}$ mass; $E$ - transpiration rate; $\mathrm{FM}$ - fresh mass; $\mathrm{F}_{0}-$ minimal fluorescence yield of the dark-adapted state; $F_{m}$ - maximal fluorescence yield of the dark-adapted state; $F_{v}$ - variable fluorescence; $F_{v} / F_{m}$ - maximal photochemical efficiency of PSII; $g_{\mathrm{s}}$ - stomatal conductance; $\mathrm{L}_{\mathrm{s}}-$ stomatal limitation; $\mathrm{MC}$ - mesophyll conductance; $P_{\mathrm{N}}$ - net photosynthetic rate; WUE - wateruse efficiency $\left(=P_{\mathrm{N}} / E\right)$.

Acknowledgments: This work was supported by the key project (No. 14ZA0008) and the science and technology activities of international students' project at Sichuan provincial education department, China. 
(Wang et al. 2011). The cultivated soybean, as the main food crop in the world, has been reported to be Cd sensitive (Finger-Teixeira et al. 2010). It is hypothesized that the yield of cultivated soybean could increase by enhancing its tolerance to $\mathrm{Cd}$. However, the limited germplasm resources and genetic knowledge on cultivated soybean have become bottlenecks for soybean breeding (He et al. 2016). Wild soybean, the direct precursor of cultivated soybean, widely populates the East Asian continent and the Japanese archipelago (He et al. 2016). A wide spectrum of ecological and morphological types of Chinese wild soybean has been observed (Wang et al. 2001), which provides an original source of information on genes and traits for cultivating and breeding soybeans (Wang et al. 2011). The genetic base of wild soybean demonstrates biological diversity and evidence of eminent resistance genes and serves as an important germplasm resource for genetic improvement of cultivated soybean.

$G$. soja is widely distributed in Dongying of Shangdong province, which belongs to the Yellow River

\section{Materials and methods}

Cultivation conditions: Several hundred Dongying wild soybean seeds were scratched with sandpapers and disinfected with $0.1 \% \mathrm{HgCl}_{2}$ solution for $10 \mathrm{~min}$, and then washed with deionized water about ten times. The seeds were then kept in the deionized water at room temperature overnight. On the next day, the seeds were put in large standard Petri dishes (50 seeds per each dish), and incubated in a growth chamber $\left(28 / 22^{\circ} \mathrm{C}, 16 / 8 \mathrm{~h}, 80 \%\right.$ humidity) until the first cotyledons appeared. After $7 \mathrm{~d}$, the healthy seedlings that were growing consistently were transplanted into polyethylene pots (diameter of $18 \mathrm{~cm}$, depth of $20 \mathrm{~cm})$ with vermiculite and perlite $(3: 1, \mathrm{v} / \mathrm{v})$ mixed with $1 / 2$ Hoagland solutions. A total of eight seedlings were placed in each pot. Seven days later, five consistent seedlings from each pot were kept.

Solutions containing different $\mathrm{Cd}$ concentrations $(0$, $0.25,0.5,1,2,4$, and $8 \mathrm{~kg} \mathrm{~m}^{-3}$ ) were prepared with $\mathrm{CdCl}_{2} \cdot 2.5 \mathrm{H}_{2} \mathrm{O}$. Three pots containing 15 seedlings were used in each treatment. Throughout the entire cultivation period, the seedlings were treated with $500 \mathrm{ml}$ of each solution once a week.

Leaf color was observed at $30 \mathrm{~d}$ after exposure to $\mathrm{Cd}$ stress. The biomass, Chl and carotenoids (Car) content, photosynthetic traits, and atomic absorption parameters were measured at $60 \mathrm{~d}$ after stress.

Leaf color and biomass: Pictures of the secondary leaves from the parietal lobes were taken under a stereomicroscope (Olympus SZX16, Olympus, Tokyo, Japan). For biomass, ten plants were selected randomly from each treatment. The shoots and the roots of seedlings were washed with distilled water, then placed in an oven $\left(70^{\circ} \mathrm{C}\right)$ overnight until their masses were constant. delta in China. This area is known for its saline and alkaline content and plants in Dongying generally demonstrated a certain resistance to salt and alkali (Wang et al. 2016). Previous report has demonstrated that Mediterranean saltbush, Atriplex halimus L., is capable of growing in saline alkali soil and is Cd tolerant (Manousaki et al. 2009). Based on this observation, we infer that Dongying wild soybean may also harbor certain tolerance to $\mathrm{Cd}$. If this ecotype of wild soybean is resistant to $\mathrm{Cd}$, it could serve as an important germplasm resource for breeding Cd-resistant cultivated soybean.

In the present study, Dongying wild soybean was treated with solutions of different $\mathrm{Cd}$ concentrations $\left(0-8 \mathrm{~kg} \mathrm{~m}^{-3}\right)$. The biomass, photosynthetic pigment content, chlorophyll fluorescence $(\mathrm{CF})$ parameters, photosynthesis traits, and the $\mathrm{Cd}$ contents were investigated. Furthermore, $\mathrm{Cd}$ tolerance of Dongying wild soybean was also assessed. Our results could provide important scientific insights for future studies on breeding $\mathrm{Cd}$ resistant cultivated soybean.

Chl and Car contents: Ten plants at the same developmental stage were selected from each treatment group and the secondary leaves from the parietal lobes were harvested. Chl and Car were isolated according to Li et al. (2013). The Chl and Car contents were measured by UVVIS spectrophotometer (UV-1750, Shimadzu, Kyoto, Japan) (Cherian et al. 2008).

Chl fluorescence was measured in intact leaves with a multifunctional modulation fluorescence imaging system (MINI-IMAGING-PAM, Walz, Effeltrich, Germany). The leaves were kept in darkness for $30 \mathrm{~min}$. The minimal fluorescence yield of the dark-adapted state $\left(\mathrm{F}_{0}\right)$, the maximal fluorescence yield of the dark-adapted state $\left(\mathrm{F}_{\mathrm{m}}\right)$, and variable fluorescence $\left(\mathrm{F}_{\mathrm{v}}\right)$ were measured. $\mathrm{F}_{0}$ induced by weak modulation light $[0.05 \mu$ mol(photon) $\mathrm{m}^{-2} \mathrm{~s}^{-1}$ ] were measured using the back of the leaf. $F_{\mathrm{m}}$ was induced by strong saturation flash $[6,000 \mu \mathrm{mol}$ (photon) $\mathrm{m}^{-2} \mathrm{~s}^{-1}$. Ten readings were collected for each treatment. $\mathrm{F}_{\mathrm{v}} / \mathrm{F}_{\mathrm{m}}$ was calculated using the formula $\mathrm{F}_{\mathrm{v}}=\mathrm{F}_{\mathrm{m}}-\mathrm{F}_{0}$ (Küpper 2007, Li et al. 2013, Khan et al. 2015).

Photosynthetic traits: Characteristics were assessed using portable photosynthesis instrument (GFS-3000, Walz, Effeltrich, Germany). The net photosynthetic rate $\left(P_{\mathrm{N}}\right)$ was measured at 14:00-16:00 h. Stomatal conductance $\left(g_{\mathrm{s}}\right)$, intercellular $\mathrm{CO}_{2}$ concentration $\left(C_{\mathrm{i}}\right)$, and transpiration rate $(E)$ were measured using the secondary leaves from the phyllophore. The temperature, relative humidity, and ambient $\mathrm{CO}_{2}$ concentration at the time of measurement were $31.1 \pm 0.9^{\circ} \mathrm{C}, 62.6 \pm 2.0 \%$, and $3.3 \pm 0.1 \mu \mathrm{mol}\left(\mathrm{CO}_{2}\right)$ $\mathrm{mol}^{-1}$, respectively. Water-use efficiency (WUE), mesophyll conductance (MC), and stomatal limitation $\left(\mathrm{L}_{\mathrm{S}}\right)$ 
were calculated according to Wei et al. (2004), Li et al. (2013), and Nwugo et al. (2008).

Cd contents: The experiments were pretreated according to Nwugo et al. (2008). The Cd contents of different tissues were measured with a continuous light source atomic absorption spectrophotometer (ContrAA700, Analytik Jena, Jena, Germany).

\section{Results}

Biomass: Comparing with control, the DM of shoots, roots, and whole plants decreased when the concentration of $\mathrm{Cd}$ increased to $2 \mathrm{~kg} \mathrm{~m}^{-3}$, however, no significant difference was observed (Table 1). Interestingly, a significant downward trend was observed regarding the $\mathrm{DM}$ of shoots, roots, and whole plants when $\mathrm{Cd}$ concentrations were further increased to $4 \mathrm{~kg} \mathrm{~m}^{-3}$ and $8 \mathrm{~kg} \mathrm{~m}^{-3}$ (Table 1).

Leaf color: The leaf color of the control started as green (Fig. 1A), which gradually faded with increasing $\mathrm{Cd}$ concentration. When the Cd stress concentration reached $2 \mathrm{~kg} \mathrm{~m}^{-3}$, the leaf color was Kelly green (Fig. $1 B$ ). When the $\mathrm{Cd}$ concentration was at $8 \mathrm{~kg} \mathrm{~m}^{-3}$, lots of maculopathy were observed on the now yellow leaves (Fig. 1C).

Table 1. Effects on the biomass of wild soybean upon exposure to $\mathrm{Cd}$ stress. Values represent mean $\pm \mathrm{SD}$. $\mathrm{a}, \mathrm{b}$ - the significant differences at $p=0.05$. DM - dry mass.

\begin{tabular}{llll}
\hline $\mathrm{Cd}\left[\mathrm{kg} \mathrm{m}^{-3}\right]$ & Shoot DM [g] & Root DM [g] & Total plant DM [g] \\
\hline 0.00 & $1.12 \pm 0.18^{\mathrm{a}}$ & $0.80 \pm 0.02^{\mathrm{a}}$ & $1.92 \pm 0.20^{\mathrm{a}}$ \\
0.25 & $0.77 \pm 0.01^{\mathrm{ab}}$ & $0.58 \pm 0.10^{\mathrm{a}}$ & $1.36 \pm 0.11^{\mathrm{ab}}$ \\
0.50 & $0.67 \pm 0.15^{\mathrm{ab}}$ & $0.48 \pm 0.43^{\mathrm{a}}$ & $1.15 \pm 0.58^{\mathrm{ab}}$ \\
1.00 & $0.86 \pm 0.50^{\mathrm{a}}$ & $0.39 \pm 0.22^{\mathrm{a}}$ & $1.24 \pm 0.72^{\mathrm{a}}$ \\
2.00 & $0.87 \pm 0.39^{\mathrm{a}}$ & $0.52 \pm 0.29^{\mathrm{a}}$ & $1.39 \pm 0.68^{\mathrm{a}}$ \\
4.00 & $0.44 \pm 0.10^{\mathrm{b}}$ & $0.17 \pm 0.03^{\mathrm{b}}$ & $0.61 \pm 0.06^{\mathrm{b}}$ \\
8.00 & $0.30 \pm 0.17^{\mathrm{b}}$ & $0.10 \pm 0.07^{\mathrm{b}}$ & $0.41 \pm 0.24^{\mathrm{b}}$ \\
\hline
\end{tabular}

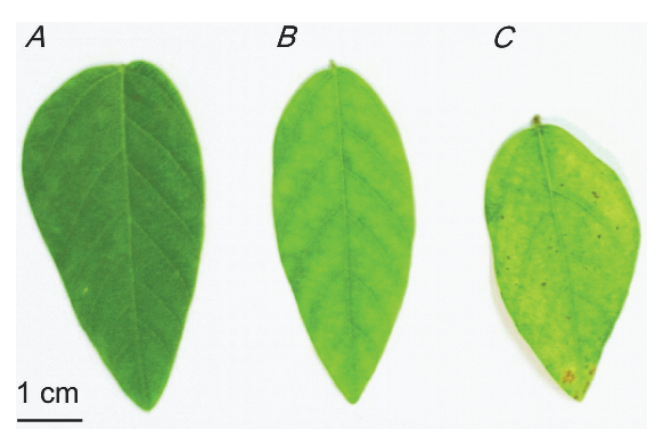

Fig. 1. The leaf color of Dongying wild soybean. Photos were taken after 30-d exposure to Cd stress; $A, B, C$ : Cd concentrations of the treatment solution were 0,2 , and $8 \mathrm{~kg} \mathrm{~m}^{-3}$, respectively.
Statistical analyses: All experiments were repeated three times. The values in tables represent means \pm SD. Statistical analyses were performed with Microsoft Excel and analyses of variance (ANOVA) by SPSS (ver. 17 Inc.). Statistical significance was assessed by Duncan's multiple range test $(p<0.05)$. The graphs were drawn using Origin 8.1.

Chl and Car: As Cd concentration increased to $0.5 \mathrm{~kg} \mathrm{~m}^{-3}$, the $\mathrm{Chl} b$ and Car contents also increased significantly compared with control. Interestingly, as the $\mathrm{Cd}$ concentrations further increased to $8 \mathrm{~kg} \mathrm{~m}^{-3}, \mathrm{Chl}$ and Car contents gradually decreased and a significant reduction was observed in comparison with the control (Table 2).

Table 2. The concentrations of $\mathrm{Chl}$ in wild soybean under $\mathrm{Cd}$ stress. Values represent mean $\pm \mathrm{SD}$. a, b, c - the significant differences at $p=0.05$. Chl - chlorophyll; Car - carotenoids; $\mathrm{FM}$ - fresh mass.

\begin{tabular}{llll}
\hline $\begin{array}{l}\mathrm{Cd} \\
{\left[\mathrm{kg} \mathrm{m}^{-3}\right]}\end{array}$ & $\begin{array}{l}\mathrm{Chl} a \\
{\left[\mathrm{mg} \mathrm{g}^{-1}(\mathrm{FM})\right]}\end{array}$ & $\begin{array}{l}\mathrm{Chl} b \\
{\left[\mathrm{mg} \mathrm{g}^{-1}(\mathrm{FM})\right]}\end{array}$ & $\begin{array}{l}\mathrm{Car} \\
{\left[\mathrm{mg} \mathrm{g}^{-1}(\mathrm{FM})\right]}\end{array}$ \\
\hline 0.00 & $7.171 \pm 0.546^{\mathrm{c}}$ & $1.740 \pm 0.133^{\mathrm{cd}}$ & $318.553 \pm 23.334^{\mathrm{cd}}$ \\
0.25 & $7.946 \pm 0.311^{\mathrm{c}}$ & $2.148 \pm 0.184^{\mathrm{de}}$ & $376.605 \pm 18.873^{\mathrm{d}}$ \\
0.50 & $8.307 \pm 0.746^{\mathrm{c}}$ & $2.302 \pm 0.212^{\mathrm{e}}$ & $454.955 \pm 16.062^{\mathrm{e}}$ \\
1.00 & $7.106 \pm 0.355^{\mathrm{c}}$ & $1.843 \pm 0.092^{\mathrm{cd}}$ & $328.039 \pm 16.402^{\mathrm{cd}}$ \\
2.00 & $5.636 \pm 0.548^{\mathrm{b}}$ & $1.468 \pm 0.113^{\mathrm{bc}}$ & $302.370 \pm 32.918^{\mathrm{bc}}$ \\
4.00 & $4.590 \pm 0.186^{\mathrm{ab}}$ & $1.164 \pm 0.055^{\mathrm{ab}}$ & $244.980 \pm 2.370^{\mathrm{ab}}$ \\
8.00 & $3.999 \pm 0.210^{\mathrm{a}}$ & $0.992 \pm 0.045^{\mathrm{a}}$ & $204.223 \pm 3.097^{\mathrm{a}}$ \\
\hline
\end{tabular}

Chl fluorescence: $F_{0}$ significantly increased by $8.6 \%$ compared with the control when the $\mathrm{Cd}$ concentration was $0.25 \mathrm{~kg} \mathrm{~m}^{-3}$. As the $\mathrm{Cd}$ concentration reached $4 \mathrm{~kg} \mathrm{~m}^{-3}$, no significant difference was observed compared with control. Interestingly, when the Cd concentration reached $8 \mathrm{~kg} \mathrm{~m}^{-3}, \mathrm{~F}_{0}$ significantly increased by $14.2 \%$ compared with control (Fig. 2A).

When Cd concentration was $\leq 0.5 \mathrm{~kg} \mathrm{~m}^{-3}$, no significant difference in $F_{m}$ was observed between treatment groups and control. With increasing $\mathrm{Cd}$ concentrations, however, $\mathrm{F}_{\mathrm{m}}$ significantly decreased by $3.4,5.1,6.5$, and $2.7 \%$ compared with control, respectively (Fig. $2 B$ ).

With increasing $\mathrm{Cd}$ concentration, $\mathrm{F}_{\mathrm{v}} / \mathrm{F}_{\mathrm{m}}$ showed an obvious downward trend (Fig. $2 C$ ). $\mathrm{F}_{\mathrm{v}} / \mathrm{F}_{\mathrm{m}}$ was significantly reduced by $11.5,2.8,3.7,7.2,9.0$, and $13.2 \%$, respectively, under increasing $\mathrm{Cd}$ concentration treatments. It is worth noting that $\mathrm{F}_{\mathrm{v}} / \mathrm{F}_{\mathrm{m}}$ significantly decreased at $0.25 \mathrm{~kg} \mathrm{~m}^{-3} \mathrm{Cd}$. Interestingly, no significant difference from the group treated with $0.25 \mathrm{~kg} \mathrm{~m}^{-3} \mathrm{Cd}$ was observed when $\mathrm{Cd}$ concentration increased to $8 \mathrm{~kg} \mathrm{~m}^{-3}$ (Fig. 2C). 


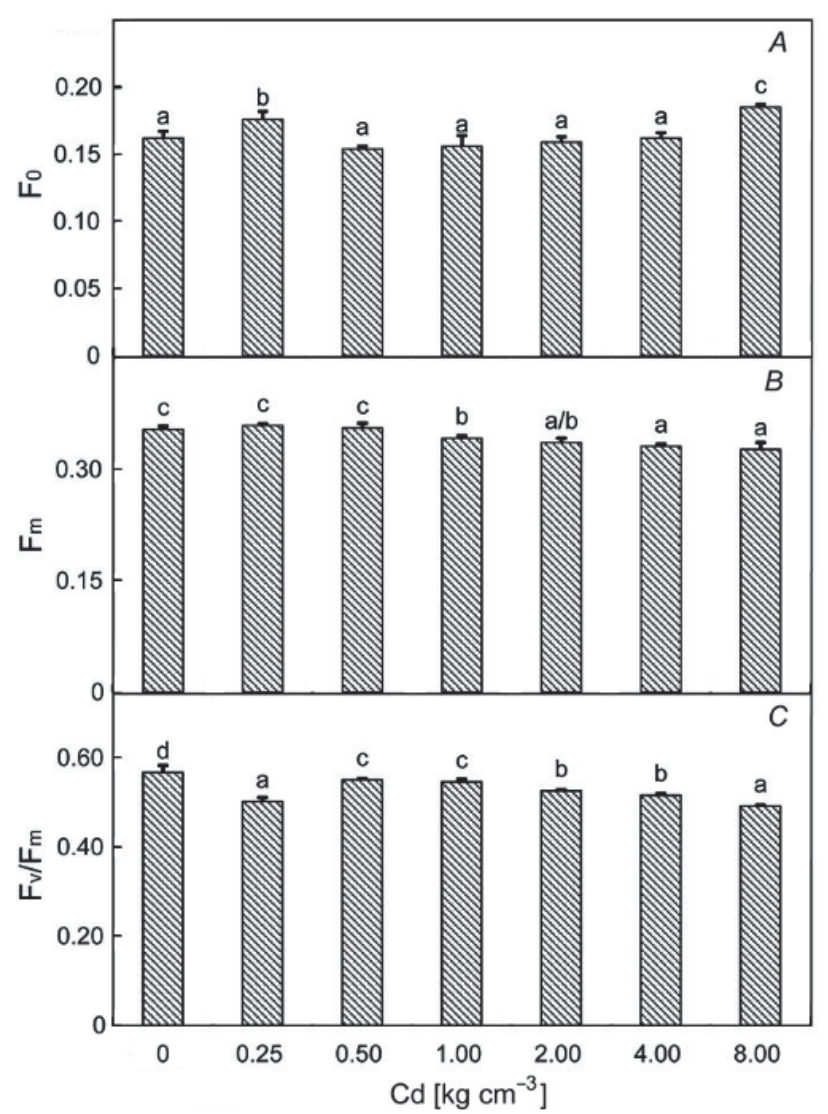

\section{Discussion}

Cd directly or indirectly inhibits a variety of physiological processes, such as respiration, photosynthesis, waterrelated processes, and gas exchange (van Assche and Clijsters 1990, Lagriffoul et al. 1998). Under Cd stress, Chl content and $\mathrm{F}_{\mathrm{v}} / \mathrm{F}_{\mathrm{m}}$ decreased, which indicates impeded photosynthesis (Parmar et al. 2013). In this study, with increasing $\mathrm{Cd}$ concentrations, leaf color was found to become more yellow, which implied that $\mathrm{Chl}$ pigment synthesis in wild soybean was inhibited. This observation
Fig. 2. Chlorophyll fluorescence parameters of Dongying wild soybean upon exposure to $\mathrm{Cd}$ stress. $\mathrm{F}_{0}$ induced by weak modulation light $\left[0.05 \mu \mathrm{mol}\right.$ (photon) $\left.\mathrm{m}^{-2} \mathrm{~s}^{-1}\right]$ was measured on the abaxial leaf surface. $\mathrm{F}_{\mathrm{m}}$ induced by strong saturation flash $\left[6,000 \mu \mathrm{mol}\left(\right.\right.$ photon) $\left.\mathrm{m}^{-2} \mathrm{~s}^{-1}\right]$. Ten readings were collected for each treatment. The experiments were repeated three times. $\mathrm{F}_{0}-$ minimal fluorescence yield of the dark-adapted state; $\mathrm{F}_{\mathrm{m}}-$ maximal fluorescence yield of the dark-adapted state; $\mathrm{F}_{\mathrm{v}} / \mathrm{F}_{\mathrm{m}}-$ maximal photochemical efficiency of PSII.

Photosynthetic characteristics: No significant changes were observed in $P_{\mathrm{N}}$, WUE, $C_{\mathrm{i}}, \mathrm{L}_{\mathrm{s}}$, and MC with increasing $\mathrm{Cd}$ concentrations. However, $g_{\mathrm{s}}$ significantly increased when $\mathrm{Cd}$ concentrations were 0.25 and $8 \mathrm{~kg} \mathrm{~m}^{-3}$. E also significantly increased when the plants were treated with 0.25 and $8 \mathrm{~kg} \mathrm{~m}^{-3} \mathrm{Cd}$ (Table 3 ).

Cd content in different tissues: The regression coefficient and the linear regression of the $\mathrm{Cd}$ standard curve were $\mathrm{y}=0.1745 \mathrm{x}+0.0012$ and $R^{2}=0.9843$, both were valid for calculating the $\mathrm{Cd}$ contents (Fig. 3). The distributions of $\mathrm{Cd}$ in seedlings exhibited a certain regularity. As shown in Table 4, with the increasing Cd concentration, the $\mathrm{Cd}$ contents in different tissues also significantly increased. When $\mathrm{Cd}$ concentration was $\leq 0.5 \mathrm{~kg} \mathrm{~m}^{-3}$, the $\mathrm{Cd}$ content in roots was always lesser than that in shoots. When $\mathrm{Cd}$ concentration was $\geq 1 \mathrm{~kg} \mathrm{~m}^{-3}$, the $\mathrm{Cd}$ content in roots was always greater than that in shoots. In the control, the $\mathrm{Cd}$ content in stems was higher than that in leaves. However, in the treatment groups, the Cd content in stems was lesser than that in leaves.

was consistent with the results shown in Table 2, which demonstrated that the $\mathrm{Chl}$ contents were reduced significantly upon exposure to Cd stress. Decreasing Chl content in leaves also limits photosynthesis. On the other hand, $\mathrm{F}_{\mathrm{v}} / \mathrm{F}_{\mathrm{m}}$ in seedlings was significantly reduced, which suggested lower functional activity of PSII (Stoeva and Bineva 2003) (Fig. 2C). Photosynthesis inhibition may be attributed to diminished $\mathrm{Chl}$ biosynthesis (Shukla et al. 2008).

Table 3. Effects on photosynthetic parameters of wild soybean upon exposure to Cd stress. Values represent mean \pm SD. $a, b-$ the significant differences at $p=0.05 . P_{\mathrm{N}}$ - net photosynthetic rate; $g_{\mathrm{s}}$ - stomatal conductance; $E$ - transpiration rate; WUE - water-use efficiency $\left(=P_{\mathrm{N}} / \mathrm{E}\right) ; C_{\mathrm{i}}-$ intercellular $\mathrm{CO}_{2}$ concentration; $\mathrm{L}_{\mathrm{s}}-$ stomatal limitation; $\mathrm{MC}-$ mesophyll conductance.

\begin{tabular}{|c|c|c|c|c|c|c|c|}
\hline $\begin{array}{l}\mathrm{Cd} \\
{\left[\mathrm{kg} \mathrm{m}^{-3}\right]}\end{array}$ & $\begin{array}{l}P_{\mathrm{N}} \\
{\left[\mu \mathrm{mol} \mathrm{m}{ }^{-2} \mathrm{~s}^{-1}\right]}\end{array}$ & $\begin{array}{l}g_{\mathrm{s}} \\
{\left[\mathrm{mmol}\left(\mathrm{H}_{2} \mathrm{O}\right) \mathrm{m}^{-2} \mathrm{~s}^{-1}\right]}\end{array}$ & $\begin{array}{l}E \\
{\left[\mathrm{mmol}\left(\mathrm{H}_{2} \mathrm{O}\right) \mathrm{m}^{-2} \mathrm{~s}^{-1}\right]}\end{array}$ & $\begin{array}{l}\text { WUE } \\
{\left[\mu \mathrm{mol}\left(\mathrm{CO}_{2}\right)\right.} \\
\left.\mathrm{mmol}^{-1}\left(\mathrm{H}_{2} \mathrm{O}\right)\right]\end{array}$ & $\begin{array}{l}C_{\mathrm{i}} \\
{\left[\mu \mathrm{mol}\left(\mathrm{CO}_{2}\right) \mathrm{mol}^{-1}\right]}\end{array}$ & $\mathrm{L}_{s}[\%]$ & $\begin{array}{l}\mathrm{MC} \\
{\left[\mathrm{mmol} \mathrm{m}^{-2} \mathrm{~s}^{-1}\right]}\end{array}$ \\
\hline 0.00 & $2.504 \pm 0.473^{\mathrm{a}}$ & $28.750 \pm 2.069^{\mathrm{a}}$ & $0.58 \pm 0.02^{\mathrm{a}}$ & $4.317^{\mathrm{a}}$ & $320.927 \pm 15.173^{\mathrm{a}}$ & $30.99^{\mathrm{a}}$ & $0.008^{\mathrm{a}}$ \\
\hline 0.25 & $3.122 \pm 0.035^{\mathrm{a}}$ & $65.586 \pm 8.797^{b}$ & $1.17 \pm 0.35^{\mathrm{b}}$ & $2.665^{\mathrm{a}}$ & $319.732 \pm 46.098^{a}$ & $25.73^{\mathrm{a}}$ & $0.010^{\mathrm{a}}$ \\
\hline 0.50 & $1.888 \pm 1.205^{\mathrm{a}}$ & $32.882 \pm 5.874^{\mathrm{a}}$ & $0.54 \pm 0.09^{\mathrm{a}}$ & $0.749^{\mathrm{a}}$ & $354.776 \pm 42.284^{\mathrm{a}}$ & $20.77^{\mathrm{a}}$ & $0.001^{\mathrm{a}}$ \\
\hline 1.00 & $2.272 \pm 0.014^{\mathrm{a}}$ & $37.179 \pm 4.348^{\mathrm{a}}$ & $0.73 \pm 0.12^{\mathrm{ab}}$ & $3.119^{\mathrm{a}}$ & $336.638 \pm 5.566^{\mathrm{a}}$ & $24.89^{\mathrm{a}}$ & $0.007^{\mathrm{a}}$ \\
\hline 2.00 & $2.344 \pm 1.138^{\mathrm{a}}$ & $30.812 \pm 7.205^{\mathrm{a}}$ & $0.62 \pm 0.16^{\mathrm{a}}$ & $3.751^{\mathrm{a}}$ & $334.664 \pm 28.854^{\mathrm{a}}$ & $26.96^{\mathrm{a}}$ & $0.007^{\mathrm{a}}$ \\
\hline 4.00 & $1.570 \pm 0.023^{\mathrm{a}}$ & $19.114 \pm 1.447^{\mathrm{a}}$ & $0.33 \pm 0.03^{\mathrm{a}}$ & $4.769^{\mathrm{a}}$ & $301.314 \pm 12.244^{\mathrm{a}}$ & $32.46^{\mathrm{a}}$ & $0.005^{\mathrm{a}}$ \\
\hline 8.00 & $2.235 \pm 1.756^{\mathrm{a}}$ & $58.687 \pm 1.925^{b}$ & $1.24 \pm 0.05^{\mathrm{b}}$ & $1.801^{\mathrm{a}}$ & $379.659 \pm 42.768^{a}$ & $15.73^{\mathrm{a}}$ & $0.006^{\mathrm{a}}$ \\
\hline
\end{tabular}




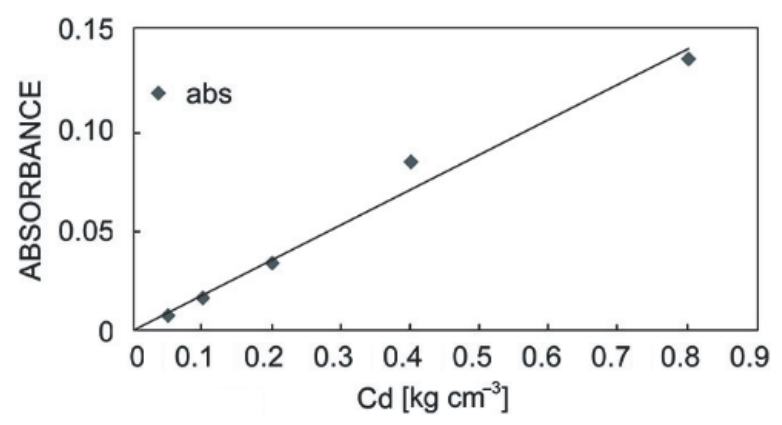

Fig. 3. Standard curve of solution at different Cd concentrations. The regression coefficient and the linear regression of the $\mathrm{Cd}$ standard curve were $\mathrm{y}=0.1745 \mathrm{x}+0.0012$ and $R^{2}=0.9843$.

Excess $\mathrm{Cd}$ in crops can disturb a series of physiological processes including respiration, photosynthesis, and nitrogen assimilation, resulting in growth inhibition (Toppi and
Gabbrielli 1999). The fact that growth of wildtype soybean was not affected by $\leq 2 \mathrm{~kg}\left(\mathrm{Cd}^{2+}\right) \mathrm{m}^{-3}$ is consistent with previously published results (Stritsis and Claassen 2013, Cornu et al. 2016). Chl biosynthesis is a physiological phenomenon linked to photosynthetic productivity of plants. Cd has been reported to inhibit $\mathrm{Chl}$ content in several plant systems (Vassilev et al. 1998, Jain et al. 2007). Results from this study demonstrated that $\mathrm{Chl}$ contents slightly increased at $\leq 0.5 \mathrm{~kg}(\mathrm{Cd}) \mathrm{m}^{-3}$. Moreover, when treated with $0.25 \mathrm{~kg}(\mathrm{Cd}) \mathrm{m}^{-3}, \mathrm{~F}_{\mathrm{v}} / \mathrm{F}_{\mathrm{m}}$ was significantly reduced. However, when $\mathrm{Cd}$ concentration increased to 4 $\mathrm{kg} \mathrm{m}^{-3}, \mathrm{~F}_{\mathrm{v}} / \mathrm{F}_{\mathrm{m}}$ increased significantly compared to that treated with $0.25 \mathrm{~kg}(\mathrm{Cd}) \mathrm{m}^{-3}$ (Fig. 2). Low dose stimulation and high dose inhibition by $\mathrm{Cd}$, termed as 'hormesis', has been observed in several organisms (Kumar et al. 2004, Jain et al. 2007, Cornu et al. 2016). For $g_{\mathrm{s}}$, there was no significant difference when the Cd concentration was $\leq 4 \mathrm{~kg}$ $\mathrm{m}^{-3}$ except for $0.25 \mathrm{~kg}(\mathrm{Cd}) \mathrm{m}^{-3}$ (Table 3 ).

Table 4. The Cd content in different tissues of wild soybean under Cd stress. Values represent mean $\pm \mathrm{SD}$. a, b, c, d, e, f - the significant differences at $p=0.05$. Cd - cadmium; DM - dry mass.

\begin{tabular}{|c|c|c|c|c|c|}
\hline \multirow[t]{2}{*}{$\mathrm{Cd}\left[\mathrm{kg} \mathrm{m}^{-3}\right]$} & \multicolumn{5}{|c|}{ Cd contents in different tissues of wild soybean $\left[\mathrm{mg} \mathrm{g}^{-1}(\mathrm{DM})\right]$} \\
\hline & Root & Steam & Leaf & Shoot & Plant \\
\hline 0.00 & $0.0187 \pm 0.0065^{\mathrm{a}}$ & $0.0144 \pm 0.0048^{\mathrm{a}}$ & $0.0110 \pm 0.0090^{\mathrm{a}}$ & $0.0254 \pm 0.0138^{\mathrm{a}}$ & $0.0440 \pm 0.0073^{\mathrm{a}}$ \\
\hline 0.25 & $0.0690 \pm 0.0071^{\mathrm{a}}$ & $0.0209 \pm 0.0082^{\mathrm{ab}}$ & $0.0527 \pm 0.0021^{\mathrm{ab}}$ & $0.0736 \pm 0.0102^{\mathrm{b}}$ & $0.1425 \pm 0.0173^{\mathrm{ab}}$ \\
\hline 0.50 & $0.1010 \pm 0.0115^{\mathrm{a}}$ & $0.0380 \pm 0.0016^{\mathrm{abc}}$ & $0.0852 \pm 0.0146^{\mathrm{bc}}$ & $0.1232 \pm 0.0162^{\mathrm{c}}$ & $0.2242 \pm 0.0048^{\mathrm{b}}$ \\
\hline 1.00 & $0.3853 \pm 0.0593^{\mathrm{b}}$ & $0.0448 \pm 0.0044^{\mathrm{bc}}$ & $0.1236 \pm 0.0023^{\mathrm{cd}}$ & $0.1684 \pm 0.0021^{\mathrm{cd}}$ & $0.5537 \pm 0.0572^{\mathrm{c}}$ \\
\hline 2.00 & $0.4569 \pm 0.0164^{\mathrm{b}}$ & $0.0541 \pm 0.0051^{\mathrm{c}}$ & $0.1470 \pm 0.0021^{\mathrm{d}}$ & $0.2010 \pm 0.0071^{\mathrm{d}}$ & $0.6579 \pm 0.0092^{c}$ \\
\hline 4.00 & $0.8202 \pm 0.0492^{\mathrm{c}}$ & $0.0559 \pm 0.0050^{\mathrm{c}}$ & $0.2220 \pm 0.0301^{\mathrm{e}}$ & $0.2779 \pm 0.0252^{\mathrm{e}}$ & $1.0980 \pm 0.0240^{\mathrm{d}}$ \\
\hline 8.00 & $3.4427 \pm 0.1264^{\mathrm{d}}$ & $0.0915 \pm 0.0155^{\mathrm{d}}$ & $0.4181 \pm 0.0026^{\mathrm{f}}$ & $0.5096 \pm 0.0129^{f}$ & $3.9522 \pm 0.1135^{\mathrm{e}}$ \\
\hline
\end{tabular}

$\mathrm{Cd}$ that entered the guard cells and combined with $\mathrm{Ca}^{2+}$ causes stomatal closure, which leads to a decrease in $\mathrm{CO}_{2}$ uptake or utilization. This ultimately results in overall inhibition of photosynthesis (Perfus-Barbeoch et al. 2002, Pietrini et al. 2010). In this study, the conductance of $\mathrm{CO}_{2}$ was not significantly affected when $\mathrm{Cd}$ concentration was $\leq 4 \mathrm{~kg} \mathrm{~m}^{-3}$ (Table 3). Taken together, Dongying wild soybean responded to the abiotic stimuli and adapted to the environment when Cd concentrations was $\leq 2 \mathrm{~kg} \mathrm{~m}^{-3}$.

Plants can reduce $\mathrm{Cd}$ toxicity through a variety of mechanisms, including excretion and the production of ROS scavengers and Cd-binding factors (Siripornadulsil et al. 2002). The ability of plants to accumulate different amounts of $\mathrm{Cd}$ is tissue-specific, and plays a predominant role in the adaptation to Cd stress (Wang et al. 2008). In shoots, the allocation of $\mathrm{Cd}$ to old leaves appears to be enhanced under Cd stress (Maria et al. 2013). In roots, the restricted movement of $\mathrm{Cd}$ was observed both in the symplast and the apoplast, which can be attributed to the sequestration of $\mathrm{Cd}$ in vacuoles and to the development of apoplastic barriers, respectively. This phenomenon is referred to as the sequestration of Cd in plant roots (Lux et al. 2011). In this study, the distribution of $\mathrm{Cd}$ in seedlings was lesser in root than that in shoots at low $\mathrm{Cd}$ concentration $\left(\leq 0.5 \mathrm{~kg} \mathrm{~m}^{-3}\right)$; while more distribution of $\mathrm{Cd}$ was observed in roots than that in shoots at the high $\mathrm{Cd}$ concentration $\left(\geq 1 \mathrm{~kg} \mathrm{~m}^{-3}\right.$ ) (Table 4). These results indicated that $\mathrm{Cd}$ crosses the plasma membrane via $\mathrm{Ca}^{2+}$ channels into the cytoplasm as suggested in Li et al. (2017).

Conclusion: Our results indicated that Dongying wild soybean seemed to show stronger tolerance to $\mathrm{Cd}$ at low $\mathrm{Cd}^{2+}$ concentration than at high $\mathrm{Cd}^{2+}$ concentration. It is supported by the mild promotion of dry mass, Chl content, and photosynthetic characteristics in Dongying wild soybean at lower $\mathrm{Cd}^{2+}$ concentration. Therefore, we proposed that Dongying wild soybean could serve as a valuable germplasm resource for improving the breeding of Cd tolerant soybean. 


\section{References}

Cherian S., Ramachandran V., Sudhakaran S. et al.: Cadmium uptake and distribution in tomato plants (Lycopersicon esculentum Mill). - S. Pac. J. Nat. Sci. 25: 37-42, 2008.

Ci D., Jiang D., Wollenweber B. et al.: Cadmium stress in wheat seedlings: growth, cadmium accumulation and photosynthesis. - Acta Physiol. Plant. 32: 365-373, 2010.

Cornu J.Y., Bakoto R., Bonnard O. et al.: Cadmium uptake and partitioning during the vegetative growth of sunflower exposed to low $\mathrm{Cd}^{2+}$ concentrations in hydroponics. - Plant Soil 404: 263-275, 2016.

Duxbury T.: Ecological aspects of heavy metal responses in microorganisms. - Adv. Microb. Ecol. 8: 185-235, 1985.

Finger-Teixeira A., Ferrarese M.L., Soares A. R. et al.: Cadmium-induced lignification restricts soybean root growth. - Ecotoxicol. Environ. Safe. 73: 1959-1964, 2010.

Fojtová M., Kovařík A.: Genotoxic effect of cadmium is associated with apoptotic changes in tobacco cells. - Plant Cell Environ. 23: 531-537, 2000.

He S.L., Wang Y.S., Li D.Z. et al.: Environmental and historical determinants of patterns of genetic differentiation in wild soybean (Glycine soja Sieb. et Zucc). - Sci. Rep. 6: 22795, 2016.

Jain M., Pal M., Gupta P. et al.: Effect of cadmium on chlorophyll biosynthesis and enzymes of nitrogen assimilation in greening maize leaf segments: role of 2-oxoglutarate. - Indian J. Exp. Biol. 45: 385, 2007.

Janik E., Maksymiec W., Mazur R. et al.: Structural and functional modifications of the major light-harvesting complex II in cadmium or copper-treated Secale cereale. - Plant Cell Physiol. 51: 1330-1340, 2010.

Jiang W., Liu D., Hou W.: Hyperaccumulation of cadmium by roots, bulbs and shoots of garlic (Allium sativum L.). Bioresour. Technol. 76: 9-13, 2001.

Khan M.I.R., Iqbal N., Masood A. et al.: Modulation and significance of nitrogen and sulfur metabolism in cadmium challenged plants. - Plant Growth Regul. 77: 1-11, 2015.

Kovalchuk O., Titov V., Hohn B. et al.: A sensitive transgenic plant system to detect toxic inorganic compounds in the environment. - Nat. Biotechnol. 19: 568-572, 2001.

Kumar G.P., Prasad, M.N.V.: Cadmium toxicity to Ceratophyllum demersum L.: morphological symptoms, membrane damage, and ion leakage. - Bull. Environ. Contam. Toxicol. 72: 1038-1045, 2004.

Küpper H., Parameswaran A., Leitenmaier B. et al.: Cadmiuminduced inhibition of photosynthesis and long-term acclimation to cadmium stress in the hyperaccumulator Thlaspi caerulescens. - New Phytol. 175: 655-674, 2007.

Lagriffoul A., Mocquot B., Mench M. et al.: Cadmium toxicity effects on growth, mineral and chlorophyll contents, and activities of stress related enzymes in young maize plants (Zea mays L.). - Plant Soil 200: 241-250, 1998.

Li Q.S., Lu Y.L., Shi Y.J. et al.: Combined effects of cadmium and fluoranthene on germination, growth and photosynthesis of soybean seedlings. - J. Environ. Sci. 25: 1936-1946, 2013.

Li L.Z., Tu C., Peijnenburg W.J. et al.: Characteristics of cadmium uptake and membrane transport in roots of intact wheat (Triticum aestivum L.) seedlings. - Environ. Pollut. 221: 351-358, 2017.

Lux A., Martinka M., Vaculík M., White P.J.: Root responses to cadmium in the rhizosphere: a review. - J. Exp. Bot. 62: 21-37, 2011.
Manousaki E., Kalogerakis N.: Phytoextraction of $\mathrm{Pb}$ and $\mathrm{Cd}$ by the Mediterranean saltbush (Atriplex halimus L.): metal uptake in relation to salinity. - Environ. Sci. Pollut. Res. 16: 844-854, 2009.

Maria S.D., Puschenreiter M., Rivelli A.R.: Cadmium accumulation and physiological response of sunflower plants to $\mathrm{Cd}$ during the vegetative growing cycle. - Plant Soil Environ. 59: 254-261, 2013.

Myśliwa-Kurdziel B., Strzalka K.: Influence of metals on the biosynthesis of photosynthetic pigments. - Neurochem. Res. 27: 547-557, 2002.

Nwugo C.C., Huerta A.J.: Effects of silicon nutrition on cadmium uptake, growth and photosynthesis of rice plants exposed to low-level cadmium. - Plant Soil 311: 73-86, 2008.

Parmar P., Kumari N., Sharma V.: Structural and functional alterations in photosynthetic apparatus of plants under cadmium stress. - Bot. Stud. 54: 45-50, 2013.

Perfus-Barbeoch L., Leonhardt N., Vavasseur A. et al.: Heavy metal toxicity: cadmium permeates through calcium channels and disturbs the plant water status. - Plant J. 32: 539-548, 2002.

Pietrini F., Zacchini M., Iori V. et al.: Spatial distribution of cadmium in leaves and on photosynthesis: examples of different strategies in willow and poplar clones. - Plant Biol. 12: 355-363, 2010

Shukla U.C., Murthy R.C., Kakkar P.: Combined effect of ultraviolet-B radiation and cadmium contamination on nutrient uptake and photosynthetic pigments in Brassica campestris L. seedlings. - Environ. Toxicol. 23: 712-719, 2008.

Sigfridsson K.G., Bernát G., Mamedov F. et al:: Molecular interference of $\mathrm{Cd}^{2+}$ with Photosystem II. - BBA-Bioenergetics 1659: 19-31, 2004.

Siripornadulsil S., Traina S., Verma D.P.S. et al.: Molecular mechanisms of proline-mediated tolerance to toxic heavy metals in transgenic microalgae. - Plant Cell. 14: 2837-2847, 2002.

Steinkellner H., Mun-Sik K., Helma C. et al.: Genotoxic effects of heavy metals: comparative investigation with plant bioassay. - Environ. Mol. Mutagen. 31: 183-191, 1998.

Stoeva N., Bineva T.: Oxidative changes and photosynthesis in oat plants grown in As-contaminated soil. - Bulg. J. Plant Physiol. 29: 87-95, 2003.

Stritsis C., Claassen N.: Cadmium uptake kinetics and plants factors of shoot Cd concentration. - Plant Soil 367: 591-603, 2013.

Sun Y., Zhou Q., Diao C.: Effects of cadmium and arsenic on growth and metal accumulation of Cd-hyperaccumulator Solanum nigrum L. - Bioresource Technol. 99: 1103-1110, 2008.

Timperio A.M., D'Amici G.M., Barta C. et al:: Proteomic, pigment composition, and organization of thylakoid membranes in iron-deficient spinach leaves. - J. Exp. Bot. 58: 3695-3710, 2007.

Toppi L.S.D., Gabbrielli R.: Response to cadmium in higher plants. - Environ. Exp. Bot. 41: 105-130, 1999.

Ünyayar S., Çelik A., Çekiç F.Ö. et al.: Cadmium-induced genotoxicity, cytotoxicity and lipid peroxidation in Allium sativum and Vicia faba. - Mutagenesis 21: 77-81, 2006.

van Assche F., Clijsters C.: Effects of metals on enzyme activity in plants. - Plant Cell Environ. 13: 195-206, 1990.

Vassilev A., Berova M., Zlatev Z.: Influence of $\mathrm{Cd}^{2+}$ on growth, chlorophyll content, and water relations in young barley plants. 
- Biol. Plantarum 41: 601-606, 1998.

Wang L., Cui X., Cheng H. et al.: A review of soil cadmium contamination in China including a health risk assessment. Environ. Sci. Pollut. Res. 22: 16441-16452, 2015.

Wang C., Wang X., Wu Q., et al.: [Preliminary evaluation on yielding ability of new peanut cultivars (lines) planted in saline and alkaline lands in Dongying.] - Shandong Agr. Sci. 48: 6973, 2016. [In Chinese]

Wang K.J., Li F.S., Cheema A.A.: Studies on the distribution of wild soybean (Glycine soja) in China. - Pak. J. Biol. Sci. 4: 149-155, 2001.

Wang K.J., Li X.H.: Genetic differentiation and diversity of phenotypic characters in Chinese wild soybean (Glycine soja Sieb. et Zucc.) revealed by nuclear SSR markers and the implication for intra species phylogenic relationship of characters. - Genet. Resour. Crop. Evol. 58: 209-223, 2011

Wang S., Huang D.Y., Zhu Q.H. et al.: Speciation and phytoavailability of cadmium in soil treated with cadmiumcontaminated rice straw. - Environ. Sci. Technol. 22: 26792686, 2015.
Wang X., Liu Y., Zeng G. et al.: Subcellular distribution and chemical forms of cadmium in Bechmeria nivea(L.) Gaud. Environ. Exp. Bot. 62: 389-395, 2008.

Wei B., Yang L.: A review of heavy metal contaminations in urban soils, urban road dusts and agricultural soils from China. - Microchem. J. 94: 99-107, 2010.

Wei X., Hao M., Zhang C. et al.: Effects of zinc and manganese fertilizers on maize photosynthetic performance under soil drought condition. - Plant Nutr. Fertil. Sci. 31: 255-258, 2004.

Wu F., Zhang G., Dominy P. et al.: Differences in yield components and kernel $\mathrm{Cd}$ accumulation in response to $\mathrm{Cd}$ toxicity in four barley genotypes. - Chemosphere 70: 83-92, 2007.

Yi H., Meng Z.: Genotoxicity of hydrated sulfur dioxide on root tips of Allium sativum and Vicia faba. - Mutat. Res. 537: 109114, 2003.

Zhao K., Liu X., Xu J. et al.: Heavy metal contaminations in a soil-rice system: identification of spatial dependence in relation to soil properties of paddy fields. - J. Hazard. Mater. 181: 778787, 2010. 